\title{
A Protective Effect of Thiopentone on Hypoxic Heart Muscle
}

Thiopentone and other barbiturates have been shown to protect the brain against hypoxic or ischaemic damage $[3,4]$. Dose regimes varying from 30 to $90 \mathrm{mg} \cdot \mathrm{kg}^{-1}$ body weight have been suggested $[1,6]$. This is grossly in excess of the dosage used for induction of anaesthesia which is in the range of 3 to $5 \mathrm{mg} \cdot \mathrm{kg}^{-1}$ body weight. These facts have led to the introduction of controlled trials of thiopentone in cerebral protection clinically as part of the burgeoning field of brain resuscitation [6]. The amount of thiopentone that may be used is limited by the cardiovascular effects of the drug, such as a decrease in arterial blood pressure and cardiac output [2]. As the usage of barbituarates for brain protection has been employed clinically by one of the authors (D. Sinclair) during cardiopulmonary by-pass procedures, it was decided to investigate the possible concomitant protective effects of thiopentone on the heart.

Isolated rat hearts were perfused at $37^{\circ} \mathrm{C}$ according to Langendorff at a pressure of $10.0 \mathrm{kPa}(75 \mathrm{mmHg})$. The standard perfusion medium [5] was equilibrated with $95 \% \mathrm{O}_{2}-5 \% \mathrm{CO}_{2}$ and contained glucose $\left(11 \mathrm{mmol} \cdot\right.$ litre $\left.^{-1}\right)$. For hypoxic perfusion the medium was equilibrated with $95 \% \mathrm{~N}_{2}-5 \% \mathrm{CO}_{2}$ and contained mannitol (11 mmol $\cdot$ litre $\left.^{-1}\right)$ instead of glucose. After a $15 \mathrm{~min}$ stabilization period, the hearts were perfused for $40 \mathrm{~min}$ with the hypoxic medium. Subsequently the hearts were reoxygenated for $30 \mathrm{~min}$. When required, thiopentone ( 50 or $200 \mathrm{mg} \cdot$ litre $^{-1}$ ) was added to the hypoxic medium. Samples of the effluent medium were collected and analysed for creatine kinase (CK) activity, using a Vitatron Automatic Kinetic Enzyme System (AKES) and a Boehringer CK NAC-activated kit. Enzyme activity was expressed in IU released $\cdot \min ^{-1} \cdot \mathrm{g}^{-1}$ dry heart tissue. Results were analysed for significance by Student's $t$ test, taking $P=0.05$ as the limit of significance.

During the $15 \mathrm{~min}$ stabilization period the hearts did not release measurable amounts of CK. The subsequent period of hypoxic glucose-free perfusion caused a slow CK release which amounted to $2.11 \pm 0.33 \mathrm{IU} \cdot \mathrm{min}^{-1} \cdot \mathrm{g}^{-1}$ dry weight after 40 min of hypoxia (Figure 1). Reoxygenation of the hearts resulted in an exacerbation of the $\mathrm{CK}$ release, with a peak value of $38.0 \pm 5.8 \mathrm{IU} \cdot \mathrm{min}^{-1} \cdot \mathrm{g}^{-1}$. When $50 \mathrm{mg} \cdot$ litre $^{-1}$ thiopentone was added to the hypoxic medium, the $\mathrm{CK}$ release was reduced both during hypoxia $\left(0.82 \pm 0.08 \mathrm{IU} \cdot \mathrm{min}^{-1} \cdot \mathrm{g}^{-1}\right.$ after $40 \mathrm{~min}$ of hypoxia; $P<0.05$ ) and during the reoxygenation period (peak value 


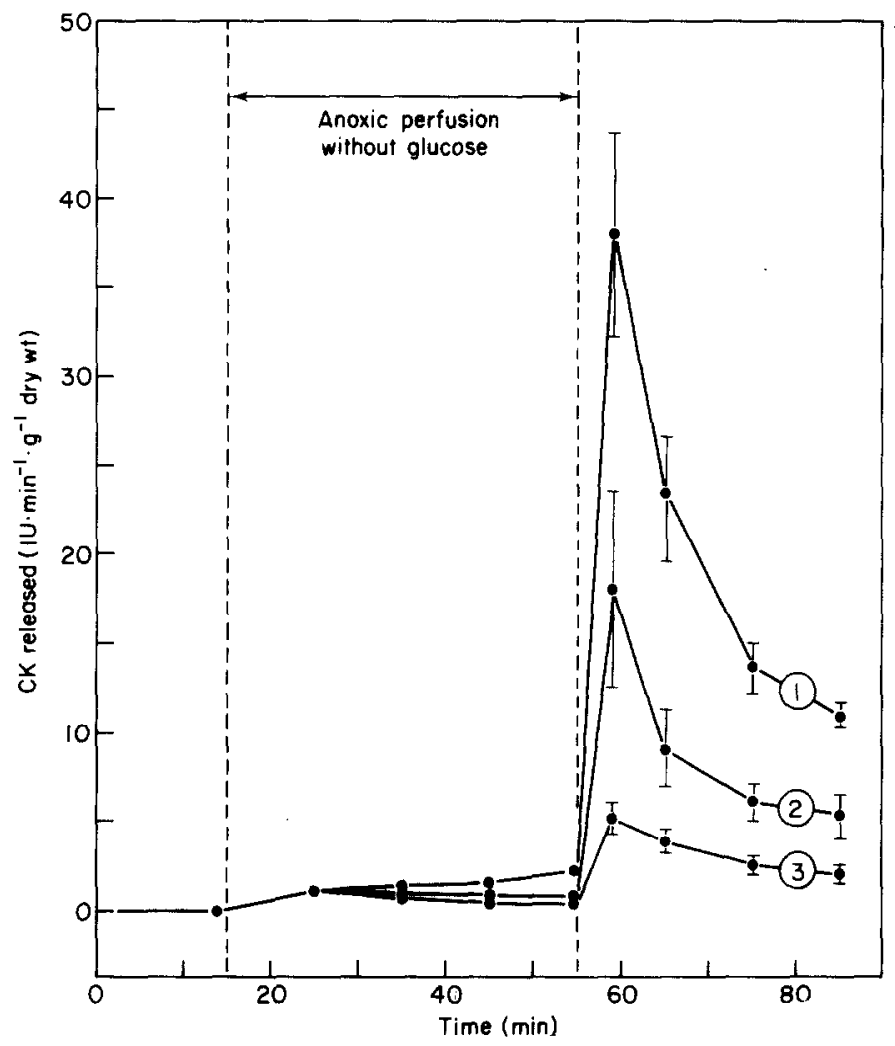

FIGURE 1. Effect of hypoxic glucose-free perfusion and subsequent reoxygenation, on the release of CK (IU $\cdot \mathrm{min}^{-1} \cdot \mathrm{g}^{-1}$ dry wt) from isolated rat heart. (1), -thiopentone; (2), $+50 \mathrm{mg} \cdot$ litre $^{-1}$ thiopentone; (3), $+200 \mathrm{mg} \cdot$ litre $^{-1}$ thiopentone. Values are given as mean \pm S.E.M. $(n=6)$.

$\left.18.0 \pm 5.5 \mathrm{IU} \cdot \mathrm{min}^{-1} \cdot \mathrm{g}^{-1} ; P<0.05\right)$. Inclusion of $200 \mathrm{mg} \cdot$ litre ${ }^{-1}$ thiopentone in the hypoxic medium resulted in a further reduction of the CK release from both the hypoxic and reoxygenated hearts. The reoxygenation peak of the $200 \mathrm{mg} \cdot \mathrm{litr}^{-1}$ series $\left(5.1 \pm 0.7 \mathrm{IU} \cdot \mathrm{min}^{-1} \cdot \mathrm{g}^{-1}\right)$ was significantly lower than that of the control and the $50 \mathrm{mg} \cdot$ litre $^{-1}$ series $(P<0.001$ and $P<0.05$, respectively).

These results can be interpreted to mean that thiopentone can, at least under certain circumstances, protect heart muscle against some of the deleterious effects of hypoxia and in so doing can decrease the reoxygenation damage. Additional studies are needed to establish the basis of this protection. It is possible that the protective effect may be associated with the drug's negative inotropy which would decrease the consumption of myocardial high-energy phosphate stores during the period immediately following the onset of hypoxic perfusion. It is also possible 
that thiopentone exerts a protective effect on the cell membrane, rendering it less susceptible to damage.

\title{
Acknowledgements
}

We thank Dr A. N. E. Zimmerman and Professor Dr F. L. Meijler for supporting this study.

\author{
D. M. Sinclair \\ D. DE MoEs \\ A. B. T. J. Bolnk \\ T. J. C. Ruigrok \\ Departments of Cardiothoracic Surgery and Cardiology, \\ University Hospital, \\ 3500 CG Utrecht, \\ The Netherlands.
}

\section{REFERENCES}

1. Bleyaert, A. L., Nemoto, E. M., Safar, P., Stezoski, S. W., Mickell, J. J., Moossy, J. \& RaO, G. R. Anesthesiology 49, 390-398 (1978).

2. Dundee, J. W. \& Wyant, G. M. Intravenous Anaesthesiology. Edinburgh: Churchill Livingstone (1974).

3. Michenfelder, J. D. Anesthesiology 49, 157-158 (1978).

4. Rockoff, M. A. \& Shapiro, H. M. Anesthesiology 49, 385-387 (1978).

5. Ruigrok, 'I. J. C., Boink, A. B. T. J., Spies, F., Blok, F. J., MaAs, A. H. J. \& Zimmerman, A. N. E. Journal of Molecular and Cellular Cardiology 10, 991-1002 (1978).

6. SAfar, P. In Handbook of Critical Care Medicine, pp. 435-449. Weil, M. H. \& R. J. Henning, Eds. Miami: Symposia Specialists (1978). 